\title{
Biohydrology research after Landau 2013 conference
}

\author{
L’ubomír Lichner $^{1}$, Artemi Cerdà ${ }^{2}$, Kálmán Rajkai $^{3}$, Miroslav Tesař ${ }^{4}$ \\ ${ }^{1}$ Institute of Hydrology, Slovak Academy of Sciences, Račianska 75, 83102 Bratislava, Slovakia. \\ ${ }^{2}$ Departament de Geografia, Universitat de València, Blasco Ibàñez, 28, 46010-Valencia, Spain. \\ ${ }^{3}$ Centre for Agricultural Research, Hungarian Academy of Sciences, Institute for Soil Science and Agricultural Chemistry, \\ Herman Ottó u. 15, H-1022 Budapest, Hungary. \\ ${ }^{4}$ Institute of Hydrodynamics of the Academy of Sciences of the Czech Republic, Pod Patankou 5, Prague 6, Czech Republic.
}

Biohydrology gives a new view on hydrological research. The impact of biota on hydrological processes was a disregarded topic in the early years of hydrology research. It has been present since the 1960s, but as a "Cinderella“" research topic. It emerged as a new aspect of the hydrological processes after the $1980 \mathrm{~s}$. In the $21 \mathrm{st}$ century, it has become a well established research topic, bringing new knowledge to aid understanding on how biota influence the hydrological cycle and the rates of hydrological processes. The importance of biohydrology research is growing, and the number of conferences, publications and research projects is being doubled every decade.

The 4th Biohydrology conference, held in Landau on 21-24 May 2013, addressed many contemporary issues surrounding water scarcity, climate change and increased pressure on land. Under the motto „Bio Meets Hydrology“, it has brought together ideas and conceptions of environmental specialists from biological, chemical and physical sciences with the hydrological sciences to discuss and to merge methods and conceptions. The conference focussed on the interaction between biological and hydrological systems, including positive impacts such as water harnessing and flood mitigation, and negative aspects including threats to food production, water repellency and environmental degradation through unsustainable land use practices. In this forum, designed to get different disciplines working together, experts from hydrology, ecology, soil science, biology, geography, forestry and engineering met, and acquired new ideas for their research. Results of the most recent and advanced biohydrology research published in Special sections on biohydrology in Biologia 2013 and 2014, as well as in the Journal of Hydrology and Hydromechanics, are presented in this preface to the Thematic issue on biohydrology.

The impact of vegetation cover on soil hydrological processes was the most frequent theme studied. In the first of 6 papers dealing with the biological soil crust (BSC), Cantón et al. (this issue) evaluated the dynamics of organic carbon (OC) losses by water erosion as affected by BSC. Runoff and erosion rates, dissolved organic carbon (DOC) and organic carbon bonded to sediments $\left(\mathrm{S}_{\mathrm{d}} \mathrm{OC}\right)$ were measured during the simulated rain. The results showed different $\mathrm{S}_{\mathrm{d}} \mathrm{OC}$ and DOC for the different BSCs and also that the presence of BSCs substantially decreased total organic carbon (TOC) compared to physical soil crusts. Within BSCs, TOC losses decreased as BSCs developed, and erosion rates were lower. Crust removal caused a strong increase in water erosion and TOC losses.

Drahorad et al. (2013) estimated the changes in surface structure and wettability during BSC development on Arenosols. They found an increase in water repellency and a decrease in water sorptivity and conductivity with ongoing BSC succession. Penetration resistance data showed very stable thin surface protection by cyanobacteria in early successional BSC that is non-repellent. Later successional stages (lichen and mosses crusts) showed increased water repellency and lower water conductivity.

Fischer and Subbotina (2014) studied 157 biological soil crust (BSC) samples from all climatic regions worldwide and derived climatic and soil texture threshold values favoring BSC development. They identified 3 mean annual temperature classes for texture dependent BSC growth limitation: $(1)<9{ }^{\circ} \mathrm{C}$ with a threshold value of $25 \%$ silt and clay (limited growth on coarser soils), (2) $9-19^{\circ} \mathrm{C}$, where texture did not have influence on relative crust biomass, and $(3)>19^{\circ} \mathrm{C}$ for soils with $<4$ or $>17 \%$ silt and clay.

Fischer et al. (this issue) identified two feedback mechanisms for BSCs, mosses and lichens on tertiary substrate of a minesite recultivation area. Sealing of the surface by crust organisms resulted in accumulation of pyrite weathering products and of components of atmospheric deposition within the crust layer, promoting the development of a community adopted to high ionic strength in the soil solution and to low $\mathrm{pH}$ (high nutrient low hydraulic feedback). On the opposite, high infiltration caused leaching of these components into deeper soil where a low nutrient high hydraulic feedback mechanism has established. These synergic feedback mechanisms contributed to the generation of self-organized surface patchiness.

Kidron (this issue) described the construction of specific runoff plot capable of measuring the runoff amount which reaches concave surfaces such as depression. He found that the playa plots at the semi-flat fine-grained sediments yielded the highest amounts of runoff (although not significantly different from sink plots at the depressions within the interdune) despite the absence of BSCs there. The crusted plots (cyanobacterial crust) on the north-facing slope yielded the lowest amounts of runoff.

Lázaro and Mora (2014) evaluated the effect of rain and BSC types (cyanobacterial and lichen crusts) as well as slope length on the ability of BSCs to protect soil from erosion. They concluded that the BSCs strongly protected soil against water erosion, even under the most erosive conditions, and the protection increased with the successional development. The plot length often had no effect on erosion, due to the decrease in erosion as a result of the protective role of BSCs, the limited runoff lengths and the increase of surface roughness, which facilitated sediment deposition.

In the first of 15 papers dealing with the impact of plants on soil hydrological processes, Bartík et al. (2014) studied the impact of the mature spruce stand (open space in the forest, open meadow area, living and dead forest) on the accumulation and melting of snow cover. They found that the processes of snow accumulation and melting were fastest at the open space 
followed by the dead forest, while they were the slowest ones in the living forest.

Dohnal et al. (this issue) estimated rainfall interception and spatial variability of throughfall in Norway spruce (Picea abies (L.) Karst.) stand. The total interception loss was determined based on precipitation measured in open area and under the trees; it was 36\% for the period from June to October 2012 and $33 \%$ for the same period in 2013. Throughfall exhibited high variability from place to place and it was strongly affected by character of rainfall. On the other hand, spatial pattern of throughfall in average showed low variability.

Dvořáková et al. (this issue) used both the two-zone and three-zone linear storage model for simulation of the runoff process during dry periods, when a part of the runoff is depleted from the riparian zone by evapotranspiration. They determined the time lag between maximum evapotranspiration and minimum streamflow, and the streamflow discharges that are "missing" during the day-part of each diurnal cycle.

Farkas et al. (2014) evaluated the effects of climate change on soil water balance elements and soil water regime in the Bükk Mountains (Hungary). Model runs using SWAP model were performed for combinations of four distinctive soil types and three land use systems of arable land, grassland, and forest. The climate data consisted of the predictions of two regional climate models, the Swiss CLM and the Swedish RCA. The RCA results showed $45 \%$ to $50 \%$ and the CLM showed $5 \%$ to $14 \%$ higher future precipitation outlook compared to present conditions.

Jian et al. (2014) evaluated the hydrological effects of Caragana korshinskii Kom. They combined the measured data with the model-simulated ones to assess the $C$. korshinskii soil water content based on water balance equation. It was found that the temporal variations in soil water content (with either measured or simulated components) had a good agreement with those measured in situ.

Lichner et al. (2013) dealt with the Scots pines (Pinus sylvestris), used for sand dune stabilization. They found that pine can influence the hydrophysical parameters and water flow in an aeolian sandy soil considerably, mainly due to soil water repellency. Water and ethanol sorptivities, hydraulic conductivity, and saturated hydraulic conductivity in the forest soil were $1 \%, 84 \%, 2 \%$ and $26 \%$ those of the pure sand, respectively. The change in soil hydrophysical parameters resulted in preferential flow in the forest soil, emerging during a simulated heavy rain following a long hot, dry period.

Lichner et al. (2014) evaluated the heterogeneity of water flow in sandy loam soil covered by grass during controlled field irrigation experiment performed at two parallel plots with different irrigation intensities. Effective cross section and degree of preferential flow parameters were used to evaluate flow regime during the experiment. For both plots, the heterogeneity of water flow increased with depth. The differences in irrigation intensity did not result in different values of the effective cross section and degree of preferential flow, indicating similar flow regime within the two experimental plots.

Lozano et al. (2014) investigated how variable SWR persistence in the field is related to the soil microbial community under different plant species ( $P$. halepensis, $Q$. rotundifolia, $C$. Albidus and $R$. officinalis) in a Mediterranean forest. The Principal Component Analysis showed that microorganism composition was more dependent of the severity of SWR than the type of plant species. The authors provided further evidence that soil hydrology and microbial communities are closely linked properties in soils.
Martins et al. (2013) assessed how terracing affected overland flow and associated sediment losses in recently burnt stands of the two principal forest types in north-central Portugal, i.e. mono-specific stands of Maritime Pine and Eucalypt. They found that (i) runoff coefficients during the first 7 months following the wildfire were similar for the Pine and the Eucalypt plantation, (ii) observed/inferred annual erosion rates over the first two years following the wildfire were also comparable at the two study sites, (iii) terracing seemed to enhance overland flow generation, and (iv) terracing appeared to increase erosion rates at both study sites by at least one order of magnitude.

Mori et al. (2013) analysed data on soil water content obtained on a steep slope near a ridge in a forested mountain range in south-western Japan. They constructed a simple prediction model by improving the "bucket with a bottom hole" model, and applied it to experimental data obtained on a forested slope to simulate the dynamics of soil moisture beneath the forest floor. The simulated soil moisture agreed reasonably with observed values on a daily to inter-seasonal timescale.

Nadezhdina et al. (2014) studied the long-term water uptake of Douglas-fir and Norway spruce trees with aim of comparing sap flow in small roots with flow in stems. They found that Douglas-fir is able to take water from deeper soil more efficiently than spruce. This allows Douglas-fir to transpire more water especially during drought and grow faster than spruce. These biological features should be taken into account for future forest species compositions because they may have impact on both forestry and hydrology.

Šípek and Tesař (2014) investigated the influence of the forest canopy (Norway spruce and beech) and altitude (ranging from $835 \mathrm{~m}$ a.s.l. to $1118 \mathrm{~m}$ a.s.l.) on the snow cover characteristics (snow depth and snow water equivalent). Forest cover had a significant influence on the snow cover accumulation, reducing snow water equivalent by about $50 \%$ compared to open sites. The elevation gradient of snow water equivalent ranged from 30 to $40 \mathrm{~mm}$ and from 5 to $20 \mathrm{~mm}$ per $100 \mathrm{~m}$ in open and forested sites, respectively. The magnitude was temporarily variable and positively related to the total seasonal snowfall amount.

Střelcová et al. (2013) estimated the differences in transpiration of Norway spruce (Picea abies (L.) Karst.) drought stressed trees and trees well supplied with water. During the second half of the 2009 vegetation period, the decrease in soil water content was observed and irrigation was applied to a group of spruce trees, while the second group was treated under natural soil drought. It was found that the transpiration of non-irrigated trees was $40.3 \%$ of the transpiration of irrigated trees during this period.

Wine and Hendrickx (2013) assessed the biohydrologic effects of eastern redcedar (Juniperus virginiana) encroachment into grassland. They found that increasing the duration of the growing season in north-central Oklahoma's water-limited climate from seven months (April - October) for grass to 12 months for redcedar increased modeled evapotranspiration only marginally, from $95 \%$ to $97 \%$ of precipitation. However, this increase in evapotranspiration with woody encroachment into grassland corresponded to a two-thirds reduction in deep drainage.

Zhang et al. (this issue) conducted the simulated rainfall experiments in laboratory to quantify the effect of patchy distributed grass Artemisia capillaris on overland flow resistance (parameterized by the Darcy-Weisbach friction coefficient) under varied rainfall intensities. The removal of grass shoots significantly reduced the friction coefficient. A 
negative relationship was found between mean friction coefficoefficient for the bare plot and rainfall intensity, whereas for grass patterned plots the relative Darcy-Weisbach friction coefficient increased exponentially with rainfall intensity.

In the first of 14 agrohydrology papers, Csorba et al. (this issue) modelled the soil water content variations under drought stress on soil column cropped with winter wheat. They concluded that the SWAP mathematical model could satisfactorily describe the hydrological processes in the soilplant-atmosphere system under climatic conditions falling outside the range the model was developed for. Therefore, it can be used for assessing the effects of predicted climate change on soil water regime and corresponding changes in plant available water content, and could successfully be applied to assess the drought stress tolerance of new crop genotypes.

Dušek et al. (2013) monitored the transport of radioactive iodide ${ }^{131} \mathrm{I}^{-}$in a black clay loam soil under spring barley in an early ontogenesis phase during controlled field irrigation experiment. It was found that iodide bound in the soil matrix could be mobilized by the surface leaching enhanced by mechanical impact of water drops and transported below the root zone of crops via soil cracks. Simulation with the onedimensional dual-continuum model S1D Dual predicted relatively deep percolation of iodide within a short time, in a good agreement with the observed vertical iodide distribution in soil.

Enku et al. (2014) studied how river low flows have been impacted by new developments in irrigation and by landscape change. They found a statistically significant decreasing trend of low flow in the Gilgel Abay River in Ethiopia. They indicated that the low flows decreased more rapidly in the middle of the nineteen nineties, after irrigation projects and eucalyptus plantations increased greatly. Specifically, from 1980 's to 1990 's the low flow decreased by $25 \%$ and from 1990 's to 2000 's the low flow was reduced by $46 \%$.

Horel et al. (2014) monitored the transport of radioactive iodide ${ }^{131} \mathrm{I}^{-}$in a structured clay loam soil under maize in a final growing phase during five consecutive irrigation experiments under ponding. The iodide transport through structured soil profile was simulated by the HYDRUS 1D model. The model predicted relatively deep percolation of iodide within a short time, in a good agreement with the observed vertical iodide distribution in soil. The authors found that the top $30 \mathrm{~cm}$ of the soil profile is the most vulnerable layer in terms of water and solute movement, which is the same depth where the root structure of maize can extend.

Josa et al. (2013) analyzed the topsoil macropores in clayloam soil of two plots under no-tillage and conventional tillage. They found that the conventional tillage (crop residues removed) topsoil had a larger lateral and vertical variability of macropore distribution than no-tillage topsoil. The presence of larger macropores was higher in conventional tillage compared to no-tillage. As pore size determines pore function in soil-plant relationships, soil macropores become suddenly dry and air can flow at low pressure gradients. It should be mentioned that pore shape and organic compounds drive major changes in the hydrological characteristics of agricultural soils (Czachor et al., 2013).

Leelamanie (this issue) examine the initial water repellency of organic manure amended soil, and its relation to the soil organic matter (SOM) depletion rates in the laboratory. Locally available cattle manure, goat manure, and Casuarina equisetifolia leaves were used as the organic manure amendments. The relation between water repellency and SOM content was considered to be governed by the original water repellency of added manures. The SOM contents of all the soil samples decreased with the time to reach almost steady level at about 30 days. The initial SOM depletion rates were negatively related with the initial water repellency.

Leelamanie and Karube (2014) examined the relation of soil hydrophobicity and drying temperature to water stability of aggregates of Andisol. They found that the contact angle and wetting rate (WDPT) were closely related with the water stability of aggregates. The results further confirmed that high levels of hydrophobicities induced aggregate floating, and the drying temperature had differential effects on hydrophobicity and aggregate stability depending on the hydrophobic materials present in the soil.

Mantovani et al. (this issue) studied water use and growth performance of a new bioenergy plant Igniscum Candy, which is a cultivar of the Sakhalin Knotweed (Fallopia sachalinensis). They found that the transpiration-biomass relation of Igniscum is comparable to rye and barley in terms of dry biomass production. The established deep rooting system and the rhizomes allow the plants to mobilize reserves for growth in the spring and to reach deeper soil water tables. These features enable the plant to start growing even during drought periods in late spring and early summer.

Nomiyama et al. (2013) analyzed water and salt absorption rates of maize plants under the salinized condition by applying both the concentration dependent model and the transpiration integrated model. They found that the absorption rates for salinization ions $\left(\mathrm{Na}^{+}, \mathrm{Cl}^{-}, \mathrm{Ca}^{2+}\right.$ and $\left.\mathrm{Mg}^{2+}\right)$ depended on ion mass flow through roots driven by the transpiration, and therefore the transpiration integrated model represented more accurately rates of root ion absorption.

Šír et al. (2014) recorded the oscillations of both the air temperature and tensiometric pressure in the brown forest soil (Dystric Cambisols) covered with Calamagrostis villosa, Avenella flexuosa and Vaccinium myrtilus. They concluded that the oscillations in the air temperature resulted from autonomous and self-regulated oscillations in the intensity of transpiration.

Urbanek et al. (this issue) compared soil structure stability of soil aggregates under three different tillage practices: conventional, reduced and no tillage. They found that the soil aggregates from soil under no tillage had very uniform aggregate strength and bulk density providing higher structural stability more consistent water distribution in the soil.

Végh (2013) studied the main components of drought tolerance of six maize genotypes to evaluate crop performance in water limited environments. The female parent lines had the greatest transpiration rate with the smallest dry matter accumulation in water deficiency, whereas hybrids could acquire more water from dryer soil while maintaining a lower transpiration rate.

Ward et al. (2013) evaluated the impact of residue removal on soil water contents in a sandy soil in a Mediterranean-type environment. After three years of residue removal, average ground cover in the subsequent summers (2011 and 2012) decreased from $78 \%$ to $51 \%$, and surface soil water contents decreased from $5.1 \%$ to $3.1 \%$. Tillage also significantly decreased ground cover (from $72 \%$ to $58 \%$ ) and soil water (from $4.2 \%$ to $3.9 \%$ ) during the same time period. The authors concluded that residue removal should have implications for soil health and sustainable crop production.

Yasutake et al. (2014) studied the pre-harvest temporal flooding in a catch crop field in relation to soil moisture and nutrient salt removal by root uptake. The results showed that pre-harvest temporal flooding enhanced crop growth and stomatal opening; hence, evapotranspiration (mostly transpiration) was increased to 3.5 times that of bare soil plot in 
greenhouse. Furthermore, the total nutrient (nitrogen) uptake by crops was also significantly accelerated in relation to preharvest flooding owing to the increase in crop growth. These results suggest that pre-harvest temporal flooding delivers considerable advantages for practical use in catch crop cultivation.

The results presented in the above-mentioned papers confirm that biohydrology is a complex science with significant relevance in the world today. The biohydrology research focusses on the interface between water and life, their common interactions and processes. This brings hydrologists and biologists to a common ground and allows them to share methods, techniques and scientific knowledge. This special issue demonstrates that the view of biohydrology is based on interactions of different scientific branches and the future of scientific research on biohydrology is in strengthening its relationship with other sciences. More than from just hydrology and biology, future research topics in biohydrology could come from geography, engineering, physics, chemistry, ecology, geology... and even from social and economic sciences. The research on biohydrology is of interest for biophysical sciences, but we must highlight that there are social and economical implications as well. Recent publications such as García-Orenes et al. (2009), Hallett et al. (2010) and Tejada and Benitez (2014) focussed on the interactions of life with water resources. Research on the interaction of water and life with society and economy is at the very aerly stages. García-Orenes et al. (2010) show how agriculture management affects biota and the soil quality, Gao et al. (2014) show how land use affects soil moisture and that it is affecting the life and management of the agriculture land, and Qadir et al. (2013) are researching climate change and its hydrological adaptation by society. These are some examples of the new challenges of the scientific research on biohydrology.

These research papers address the state-of-the-art of biohydrology at the end of 2014. The scientists working on the interactions of water and life are facing new challenges, such the use of new methods, developing new ideas and designing new research programs. This special issue is a step forward toward making all of these tasks more efficient and productive, and to inform the scientific community about what we know, and what we must research tomorrow.

\section{REFERENCES}

Bartík, M., Sitko, R., Oreňák, M., Slovik, J., Škvarenina, J., 2014. Snow accumulation and ablation in disturbed mountain spruce forest in West Tatra Mts. Biologia, 69, DOI: 10.2478/s11756-014-0461-x

Czachor, H., Hallett, P.D., Lichner, L., Jozefaciuk, G., 2013. Pore shape and organic compounds drive major changes in the hydrological characteristics of agricultural soils. European Journal of Soil Science, 64, 334-344.

Drahorad, S., Steckenmesser, D., Felix-Henningsen, P., Lichner, L., Rodný, M., 2013. Ongoing succession of biological soil crusts increases water repellency - a case study on Arenosols in Sekule, Slovakia. Biologia, 68, 1089 1093.

Dušek, J., Lichner, L', Vogel, T., Štekauerová, V., 2013. Transport of iodide in structured soil under spring barley during irrigation experiment analyzed using dual-continuum model. Biologia, 68, 1094-1098.

Enku, T., Taddesse, A., Lijalem, D., Alebachew, A., Belachew, M., Atanaw, F., Ayalew, M., Tilahun, S.A., Steenhuis, T.S., 2014. Biohydrological triggers for decreasing low flows in the humid Ethiopian highlands: The Gilgel Abay catchment. Biologia, 69, DOI: 10.2478/s11756-014-0462-9

Farkas, C., Gelybó, G., Bakacsi, Z., Horel, Á., Hagyó, A., Dobor, L., Kása, I., Tóth, E., 2014. Impact of expected climate change on soil water regime under different vegetation conditions. Biologia, 69, DOI: 10.2478/s11756014-0463-8

Fischer, T., Subbotina, M., 2014. Climatic and soil texture threshold values for cryptogamic cover development: A meta-study. Biologia, 69, DOI: 10.2478/s11756-014-0464-7

Gao, X., Wu, P., Zhao, X., Wang J., Shi, Y., 2014. Effects of land use on soil moisture variations in a semi-arid catchment: implications for land and agricultural water management. Land Degradation and Development, 25, 163-172.

García-Orenes, F., Cerdà, A., Mataix-Solera, J., Guerrero, C., Bodí, M.B., Arcenegui, V., Zornoza, R., Sempere, J.G., 2009. Effects of agricultural management on surface soil properties and soil-water losses in eastern Spain. Soil and Tillage Research, 106, 117-123.

García-Orenes, F., Guerrero, C., Roldán, A., Mataix-Solera, J., Cerdà, A., Campoy, M., Zornoza, R., Bárcenas, G., Caravaca, F., 2010. Soil microbial biomass and activity under different agricultural management systems in a semiarid Mediterranean agroecosystem. Soil and Tillage Research, 109, 110-115.

Hallett, P.D., Lichner, L., Cerdà, A., 2010. Biohydrology: coupling biology and soil hydrology from pores to landscapes. Ecohydrology, 3, 379-381.

Horel, A., Lichner, L., Alaoui, A., Czachor, H., Nagy, V., Tóth, E., 2014. Transport of iodide in structured clay-loam soil under maize during irrigation experiments analyzed using HYDRUS model. Biologia, 69, DOI: 10.2478/s11756-0140465-6

Jian, S.Q., Zhao, C.Y., Fang, S.M., Yu, K., 2014. Soil water content and water balance simulation of Caragana korshinskii Kom. in the semiarid Chinese Loess Plateau. J. Hydrol. Hydromech., 62, 89-96.

Josa, R., Gorchs, G., Ginovart, M., Solé-Benet, A., 2013. Influence of tillage on soil macropore size, shape of top layer and crop development in a sub-humid environment. Biologia, 68, 1099-1103.

Lázaro, R., Mora, J.-L., 2014. Sediment content and chemical properties of water runoff on biocrusts in drylands. Biologia, 69, DOI: $10.2478 / \mathrm{s} 11756-014-0466-5$

Leelamanie, D.A.L., Karube J., 2014. Water stable aggregates of Japanese Andisol as affected by hydrophobicity and drying temperature. J. Hydrol. Hydromech., 62, 97-100.

Lichner, L., Capuliak, J., Zhukova, N., Holko, L., Czachor, H., Kollár, J., 2013. Pines influence hydrophysical parameters and water flow in a sandy soil. Biologia, 68, 1104-1108.

Lichner, L., Dušek, J., Tesař, M., Šír, M., Czachor, H., Mészároš, I., 2014. Heterogeneity of water flow in grassland soil during irrigation experiment. Biologia, 69, DOI: 10.2478/s11756-014-0467-4

Lozano, E., García-Orenes, F., Bárcenas-Moreno, G., JiménezPinilla, P., Mataix-Solera, J., Arcenegui, V., MorugánCoronado, A., Mataix-Beneyto, J., 2014. Relationships between soil water repellency and microbial community composition under different plant species in a Mediterranean semiarid forest. J. Hydrol. Hydromech., 62, 101-107.

Martins, M.A.S., Machado, A.I., Serpa, D., Prats, S.A., Faria, S.R., Varela, M.E.T., Gonzalez-Pelayo, O., Keizer, J.J., 2013. Runoff and inter-rill erosion in a Maritime pine and a eucalypt plantation following wildfire and terracing in northcentral Portugal. J. Hydrol. Hydromech., 61, 261-268. 
Mori, M., Nagai, H., Ogata, T., Yasutake, D., Kitano, M., 2013. Soil moisture variability on a steep slope near a ridge in a forested mountain range, Shikoku, Japan: a model study. Biologia, 68, 1109-1112.

Nadezhdina, N., Urban, J., Čermák, J., Nadezhdin, V., Kantor, P., 2014. Comparative study of long-term water uptake of Norway spruce and Douglas-fir in Moravian upland. J. Hydrol. Hydromech., 62, 1-6.

Nomiyama, R., Yasutake, D., Sago, Y., Kitano, M., 2013. Transpiration integrated model for root ion absorption under salinized condition. Biologia, 68, 1113-1117.

Qadir, M., Noble, A.D., Chartres, C., 2013. Adapting to climate change by improving water productivity of soils in dry areas. Land Degradation and Development, 24, 12-21.

Š́ípek, V., Tesař, M., 2014. Seasonal snow accumulation in the mid-latitude forested catchment. Biologia, 69, DOI: 10.2478/s11756-014-0468-3

Šír, M., Tesař, M., Lichner, L., Czachor, H., 2014. The effect of grass cover transpiration on the air temperature. Biologia, 69, DOI: $10.2478 / \mathrm{s} 11756-014-0469-2$

Střelcová, K., Kurjak, D., Leštianska, A., Kovalčíková, D., Ditmarová, L., Škvarenina, J., Ahmed, Y.A.-R., 2013.
Differences in transpiration of Norway spruce drought stressed trees and trees well supplied with water. Biologia, $68,1118-1122$.

Tejada, M., Benítez, C., 2014. Effects of crushed maize straw residues on soil biological properties and soil restoration. Land Degradation and Development, 25, 501-509.

Végh, K.R., 2013. Root and leaf traits, water use and drought tolerance of maize genotypes. Biologia, 68, 1123-1127.

Ward, P.R., Roper, M.M., Jongepier, R., Fernandez, M.M.A., 2013. Consistent plant residue removal causes decrease in minimum soil water content in a Mediterranean environment. Biologia, 68, 1128-1131.

Wine, M.L., Hendrickx, J.M.H., 2013. Biohydrologic effects of eastern redcedar encroachment into grassland, Oklahoma, USA. Biologia, 68, 1132-1135.

Yasutake, D., Awata, K., Kondo, K., Yamane, S., Matsuoka, M., Maeda, M., Nagare, H., Nomiyama, R., Sago, Y., Kitano, M., Fujiwara, T., 2014. Advantages of pre-harvest temporal flooding in a catch crop field in relation to soil moisture and nutrient salt removal by root uptake. Biologia, 69, DOI: 10.2478/s11756-014-0470-9 